\title{
Gendered Phenomenological Perceptions on Characteristics of Sexual Harassment among Soldiers in Eastern, Zambia
}

\author{
John Mwitumwa Matakala*' Ivy Nawa Akabondo' Mubiana Macwan'gi, Philemon Ndubani, \\ Anne-Namakando Phiri \\ Department of Gender Studies, University of Zambia, Lusaka; Zambia
}

*Corresponding Author: John Mwitumwa Matakala, Department of Gender Studies, University of Zambia, Lusaka; Zambia

\begin{abstract}
This study was aimed at exploring and understanding the gendered phenomenological perceptions on the characteristics of sexual harassment of soldiers in eastern, Zambia. The motivation behind this study is that despite the measures put in place it was unclear why the phenomenon continued to exist. In order to understand the experiences, the study made use of a qualitative inquiry grounded in existential phenomenology.

Purposive Sampling using Snow ball sampling was used to come up with the desired sample size of 32 and the resultant data that were collected. Data collection was achieved by use of in-depth interviews. The data were analyzed using phenomenological analysis in order to transcribe the bulk data into themes and sub themes.

The findings were categorized in line with the objectives of the study which where (a) Nature of Sexual Harassment (b) Coping mechanisms in the face of Sexual Harassment and (c) Regulatory measurers put in place to curb Sexual Harassment.

The findings of the study on the nature of sexual harassment using in - depth interviews show that female and male soldiers of the junior ranks experience Sexual Harassment as opposed to the senior ones. Further, revealed is that the nature of Sexual Harassment experienced mostly is verbal Sexual Harassment which is dominant and manifesting itself in form of unwanted genderedcomments. Nonverbal sexual harassment through unwanted actions was a further experience for the females. It was further found out that the junior soldiers experienced these vices at platoon level from corporals and sergeants.

The findings of the study on coping of soldiers in the face of sexual harassment revealed that sexual harassment was common. Furthermore, although there was only one standard way of reporting problems to relevant authorities, the issue of sexual harassment was not taken seriously. Further findings, indicate that the junior soldiers practiced coping mechanisms which are problem fixing, where they befriend a senior officer for protection and problem sharing were they shared with a friend to lighten the stress.

The findings on regulatory measures put in place to curb sexual harassment show that there is no written instruction in the Army and indeed the United Nations hence making it difficult for soldiers to be protected.

The gendered work output may go down if the issue remains unchecked leading to low morale.

It is against this background that in order to improve the situation a number of recommendations have been put forward for consideration by the Army and the United Nations.
\end{abstract}

Keywords: Gendered Phenomenological Perceptions, Sexual Harassment.

\section{INTRODUCTION}

\subsection{Background to the Study}

Sexual harassment has become one of the gender issues that is presently of great concern not only in many communities, but also not of exclusion are the military communities.

It has also been documented and recorded that sexual harassment is on the increase in Africa, especially in the South Central African Armies during the United Nations Peace Keeping operations among soldier's interactions (UNSC, 2008).Available evidence show that the majority of soldiers are harassed when they form part of the deployment (UNSC, 2008).

Geographically Zambia falls in this category. This is of great concern as these Armies, Zambia inclusive are the major contributors of peace keepers under the United Nations mandate to war torn 
countries. The aim of peace keeping missions is to protect displaced people from rebels (UNSC, 2008).

The main measure put in place by the United Nations and various contingents to address sexual harassment, abuse and exploitation is dismissal from service and forfeiture of allowances. The measure was put in place to ban any form of sexual harassment, abuse and exploitation of the local population such as female refugee, by all UN personnel and military peace keepers whether consensual or coerced and regardless of persons involved using UN resolutions at all times (SCGR, 2008).

The measure and the ban of sexual harassment did not include soldiers on peace keeping operations, but only for the local population such as female refuges.

In Zambia, the penal code amendment no. 15 of 2005 has listed laws addressing sexual harassment in work places. An extract from section 137, subsection 1, 2 and 3 of the penal code with relevant laws on workplace sex harassment is highlighted below:

$137 A$

(1) Any person who practices sexual harassment in a work place, institution of learning or elsewhere on a child commits felony and is liable. Upon conviction, to an imprisonment for a term of not less than three years and not exceeding fifteen years' imprisonment.

(2) A child who commits an offence under subsection (1) is liable to community service or counseling as the court may determine in the best interests of the child.

(3) In this section, sexual harassment means (a) a seductive sexual advance

Being unsolicited sexual comment, physical contact or other gesture of Sexual nature that one finds to be objectionable or offensive or which Cause discomfort in one's studies or job and interferes with academic Performance or conducive working or study environment.

However, despite these measures being put in place directly or indirectly the vice has been recorded as shown by the afore mentioned theoretical literature in military communities thereby prompting a reaction from research studies.

Reading through empirical literature shows that there has since been a reaction by many research studies all with a view of coming up with mitigation measures towards the vice (Gallagher, 2008; Davidson, 2013; Deschamps, 2015; Greyson, 2010; Matakala, 2015 Miriam, 2012 and Merriam 2015).

However, from the interaction with literature it appears these research studies main focus was on the female military personnel hence a knowledge gap that compelled this study so as to include the male military personnel.

The motivation behind this inquiry is to ensure inclusiveness in coming up with mitigation measures for sexual harassment through the eliciting of gendered perceptions so as to ensure both Gender equality and equity.

\subsection{Statement of the Problem}

Gendered Phenomenological Perceptions on characteristics of sexual harassment among soldiers in eastern, Zambia has not been done.

This is a compelling knowledge gap.

\subsection{General Objective}

To explore and understand the gendered phenomenological perceptions of sexual harassment characteristics among soldiers in eastern, Zambia.

\subsection{Specific Objectives To}

- Understand the nature of sexual harassment from gendered phenomenological perceptions among soldiers.

- To establish how soldiers, cope with life in the face of sexual harassments from gendered phenomenological perceptions. 
- To identify the regulatory measures that have been put in place by the Zambia Army, to curb sexual harassment from gendered phenomenological perceptions among soldiers.

\subsection{Research Questions}

- What is the nature of sexual harassment from gendered phenomenological perceptions among soldiers?

- How do soldiers, cope with life in the face of sexual harassments from gendered phenomenological perceptions?

- What regulatory measures have been put in place by the Zambia Army, to curb sexual harassment from a gendered phenomenological perception among soldiers?

\subsection{Significance of the Study}

This study is not only going to add knowledge to the discipline of Gender Development Studies at the University of Zambia but will further avail information to both the policy implementers both in the military and the United Nations. It is also hoped that it will act as a stepping stone for further research.

\subsection{Ethical Consideration}

Ethical clearance was obtained from the ethics Committee of the University of Zambia. Thereafter, dual permission was sought involving the military authorities and the actual participants.

\subsection{Definition of Terms}

(1) Sexual harassment: Are the unwanted physical, verbal and nonverbal gestural action on a victim from the opposite sex.

(2) Gendered Phenomenological Perceptions: A combination of Female/Male victims and their lived experiences based on the sexual harassment characteristics.

(3) Soldiers: The are noncommissioned ranked personnel from the ranks of privates, lance corporals, sergeants, staff sergeants, warrant officer class two and one.

\subsection{Purpose Statement}

The purpose of this Existential Phenomenological inquiry was to uncover the meaning, articulated 'essences' of gendered phenomenological perceptions as a way of understanding the lived experiences on the characteristics of sexual harassment for soldiers in the eastern part of Zambia.

This approach facilitated the fast eliciting, of every day gendered phenomenological perceptions and ideas of the participants from the insider's view called the 'emic' perspective Holloway and Wheeler (1996). It further assisted in the articulation and amplification of the characteristics of sexual harassment by the soldiers.

Methods of inquiry included a phenomenological reflection on data elicited by existential investigation of soldiers experiences and investigation of the phenomenon in the creative arts Creswell (2009).

\subsection{Theoretical Frameworks}

The study is anchored on the theory of gender power relations and its ubiquitous nature by Michael Foucault, which states that an unwanted action physical, verbal or non-verbal can be undertaken by either sex depending who holds power in selected military bases of the Hessian inFrance (Foucault, 1975). The theory is selected to guide this study because it shows the relationship between the seniors on the juniors of the opposite sex. This is shown through the general unwanted actions on the juniors.

Furthermore, the theory was picked because it has worked in the study of (Mirriam, 2012) even though it only focused on the female cadets.

\section{Methodology}

A qualitative research approach was used grounded in the philosophy of Interpretivism in order to understand the Gendered experiences and interpretations of sexual harassment among soldiers. The research design that was used was the Existential phenomenology to get down to the Gendered 
Phenomenological Perceptions of the participants as well as allowing the researcher to bracketing his ideas by only getting views of participants Egaden (2012).

The study was conducted in the eastern part of Zambia among soldiers that had experienced sexual harassment. Judgmental and Snowball sampling were used to come up with the desired sample size of 32 in the absence of the sampling frame.

The resultant data were collected through the in-depth interview guides and the data collection procedure began with the pretest, prescribed interview process and sequential actual data collection

\subsection{Pretest}

Before the actual data collection, the interview guide was subjected to prior collection so as to standardize the research instruments so that they are able to collect the desired information.

\subsection{Interview process}

The participants were first greeted by the researcher. They were later told the purpose of the study and consent was gotten from them before the inquiry. They were also assured of confidentiality and that they had a right to pull out at any time they felt uncomfortable as it was there right before commencement of the interview.

\subsection{Sequential Transformative Strategy}

It was used to collect the data because the objectives were followed chronologically and were all qualitative by nature Creswell (2009).

The findings were thermalized chronologically in line with the first objective which was on the nature of sexual harassment, coping strategies and the regulatory measures.

The data were analyzed by the use of the phenomenological data analysis by reducing the large amounts of data by transcribing each script in order to come up with the themes and sub themes of the inquiry.

Furthermore, issues of trustworthiness were achieved through Guba's four trustworthy strategy ofcredibility, dependability, transferability and Confirmability. It falls under the volunteristic axiology which looks at ethics and aesthetics which looks at the value of the study academically. Guba and Lincoln (1994).

\subsection{Credibility}

It was ensured by choosing of the correct research design or plan which was the existential phenomenology hence the data is correct and is acceptable academically.

\subsection{Dependability}

It was done through standardizing the research instruments so that they get the desired information hence the data is correct and is acceptable academically.

\subsection{Conformability}

It was done by ensuring the phenomenological reduction or 'epoche' or bracketing of pre conceived ideas through listening and taking the information as it comes.

\subsection{Transferability}

It was done through the afore mentioned in that the study has the capacity of being contextualized with other studies so as to come up with similarities which can lead to identification of gaps by other studies.

\section{RESUlTS \& DISCUSSION}

\subsection{What is the nature of sexual harassment from gendered phenomenological perceptions?}

3.1.1. Contextualised Similarities with Other Empirical Studies

\begin{tabular}{|c|c|}
\hline $\begin{array}{l}\text { Empirical Findings on Nature of Sexual } \\
\text { Harassment from Literature Review }\end{array}$ & $\begin{array}{l}\text { Research Findings on Nature of } \text { Sexual } \\
\text { Harassment for this Study }\end{array}$ \\
\hline $\begin{array}{l}\text { - Studies by Gallagher 2008; Davidson 2013; } \\
\text { McMillan } 1993 \text { and Matakala } 2015 \text { show that } \\
\text { the nature of sexual harassment on female } \\
\text { service personnel with junior ranks were verbal } \\
\text { and non-verbal sexual harassment. }\end{array}$ & $\begin{array}{l}\text { - The findings of this study are in agreement with } \\
\text { the other female studies in that it also found } \\
\text { both verbal and non-verbal sexual harassment. } \\
\text { - The findings of this study also agree with other }\end{array}$ \\
\hline
\end{tabular}


Gendered Phenomenological Perceptions on Characteristics of Sexual Harassment among Soldiers in Eastern, Zambia

- $\quad$ Furthermore a study by Greyson (2010) and Seattle et al (2014) found the nature of sexual harassment was verbal on male junior ranks.

male studies that verbal sexual harassment is the typology of sexual harassment on male junior soldiers.

\title{
Source: Field Data (2017) and Empirical Literature
}

This is what the participants had to say when asked what the nature of sexual harassment ;

A female soldier of the rank of lance corporal when asked on the nature of sexual harassment had this to say;

"Senior male soldiers tell us that imwebakazikulibe buffalo ikazi Mwabwelakuononganchito in chinyanja meaning you females There is no female buffalo in our system of military have just come to destroy our work in English...

A male soldier of the rank of lance corporal when asked on the nature of sexual harassment commented that;

"When I failed a class test and all females in class where above Me a senior female soldier mocked me that I was a lady... ,

\subsubsection{Contextualised Disimilarities with Other Empirical Studies}

This study did not come up with findings of physical sexual harassment for females and nonverbal sexual harassment for male soldiers respectively hence this was new knowledge contributed to the academia world unlike other studies. The reason for this difference is differential cultural backgrounds.

\subsubsection{Theoretical Framework Contextualisation Agreement}

The study seems to agree with the gender power relations theory my Michael Foucault in that the findings of this study showed that the senior male or female soldiers were in the tendency of harassing of the opposite junior sex.

\subsection{How do soldiers cope in the face of sexual harassment from gendered phenomenological perceptions?}

\subsubsection{Contextualised Similarities with Other Empirical Studies}

\begin{tabular}{|l|l|}
\hline $\begin{array}{l}\text { Empirical Findings on coping mechanisms of } \\
\text { Sexual Harassment from Literature Review }\end{array}$ & $\begin{array}{l}\text { Research Findings on coping mechanisms of } \\
\text { Sexual Harassment for this Study }\end{array}$ \\
\hline $\begin{array}{l}\text { Studies by Gallagher 2008; Davidson 2013; } \\
\text { McMillan } 1993 \text { and Matakala 2015 show that } \\
\text { the females cope by avoiding the harassers. }\end{array}$ & $\begin{array}{l}\text { The findings of this study are in agreement with } \\
\text { the other female studies in that it also found } \\
\text { that the females avoid the harassers. }\end{array}$ \\
$\begin{array}{l}\text { Furthermore a study by Greyson (2010) and } \\
\text { Seattle et al (2014) found that male cope by } \\
\text { avoiding the would be harassers. }\end{array}$ & $\begin{array}{l}\text { The findings of this study also agree with other } \\
\text { male studies also found that the males avoid } \\
\text { the would be senior female harassers. }\end{array}$ \\
\hline
\end{tabular}

Source: Field Data (2017) and Empirical Literature

This is what the participants had to say when asked on how they cope in the face of sexual harassment;

A female soldier of the rank of when asked on the nature of sexual harassment had this to say;

"Ibefriend a senior person to the would be harasser for protection..."

A male soldier of the rank of lance corporal when asked on the nature of sexual harassment commented that;

\begin{abstract}
"Sir meaning the researcher in order for me to be protected I just
Start a friendship relationship with a senior female .............."
\end{abstract}

\subsubsection{Contextualised Disimilarities with Other Empirical Studies}

This study came up with findings on how to cope in the face of sexual harassment for females and males and what was revealed was that they befriend a senior to the would be harasser and this was new knowledge contributed to the academia world unlike other studies. The reason for this difference is differential cultural backgrounds. 
3.3. What regulatory measures have been put in place by the Zambia Army, to curb sexual harassment from a gendered phenomenological perception among soldiers?

\subsubsection{Contextualised Similarities with Other Empirical Studies}

\begin{tabular}{|l|c|}
\hline $\begin{array}{l}\text { Empirical Findings on the Availability and } \\
\text { Application of Programmes and Policies of Sexual } \\
\text { Harassment }\end{array}$ & $\begin{array}{l}\text { Research Findings on the Availability and } \\
\text { Application of Programmes and Policies of } \\
\text { Sexual Harassment }\end{array}$ \\
\hline $\begin{array}{l}\text { The following empirical studies found that there } \\
\text { were no regulatory measures or programmes that } \\
\text { try to combat sexual harassment with regard to } \\
\text { female soldiers - Turchic and Susan (2010), }\end{array}$ & $\begin{array}{l}\text { This study came up with similar findings } \\
\text { with regard to female and male soldiers. }\end{array}$ \\
$\begin{array}{l}\text { Deschamps and Mills (2015), Merriam (2015), } \\
\begin{array}{l}\text { Mirriam (2012) and Matakala (2015). } \\
\text { Further the following empirical studies found no } \\
\text { regulatory measure or programmes on sexual } \\
\text { harassment to combat it with regard to male } \\
\text { soldiers - Settle et al (2014) and Greyson (2010). }\end{array}\end{array}$ & $\begin{array}{l}\text { It found from both male and female responses } \\
\text { that there were no regulatory measures on } \\
\text { sexual harassment to try and combat it. }\end{array}$ \\
\hline
\end{tabular}

Source: Field Data (2017) and Empirical Literature

This is what the participants had to say when asked on the available regulatory measures for curbing sexual harassment:

A male/female soldier of private rank when asked on the availability of regulatory measures to curb sexual harassment had this to say;

\section{"kulibiletualionse ma programs yalipo in chinyanja meaning}

There are no programs on sexual harassment. what is there is

$$
\text { Is a Gender desk at Army headquarters....................? }
$$

\subsubsection{Contextualised Disimilarities with Other Empirical Studies}

While the findings on the availability of regulatory measures for curbing of sexual harassment just like other studies showed that there were no regulatory measures to curb sexual harassment that this study established, however it found, that there was a gender desk at army headquarters though in its infancy a response not seen in other studies hence new knowledge. The reason is different sensitization levels on gender issues.

\section{CONCLUSION}

This thesis is important because it bridges the gap in knowledge with other studies that only focused on the females as opposed to a combination of the female and male through a gendered phenomenological gendered perception on the sexual harassment problems.

The study did so through the nature of sexual harassment in which verbal harassment were established with regard to the male and female soldiers. Nonverbal was also established with respect for the female soldiers.

The study also did so through the coping strategies in which it established that the perpetrators were avoided by use of eluding them. It was further found that as a way of coping they befriended a senior from the opposite sex for protection.

The study also did so through the regulatory measures in which was found that there was nothing written but a new gender desk at the main headquarters.

\section{RECOMMENDATIONS}

In view of the important role that soldiers play during the execution of various military operations and in the light of the findings of this study, presented below are the recommendations.

The findings of this study inform both the Zambian Army and the United Nations to find lasting policies that should curb sexual harassment of soldiers, that will not only better Zambia army but also other Armies globally. 
This should be done in the most effective and sufficient manner as suggested below by the researcher:

- The Zambia Army must enshrine in its curriculum the subject of gender and military so that it can be learnt by all beginning with recruit training centers and officers training centers which first take individuals into the Army.

Furthermore, the same curriculum should be introduced at the military establishment as a course of specialization were unit can be sending personnel to learn gender and military in order to impart it others in their unit.

\section{RECOMMENDATIONS FOR FURTHER STUDIES}

It is recommended that that a future study must consider undertaking the development of a gendered participatory approach to prevent sexual harassment among soldiers through the use of social or emancipation action principles with the usage of the interprativist participatory approach and the interprativist emancipation phenomenology Egaden (2012).

\section{ACKNOWLEDGEMENT}

I wish to thank my supervisors Prof. Mubiana Macwan'gi and Dr. Philemon Ndubani for the guidance in this researchthesis. I further thank Dr. Anne-Namakando Phiri and all the Lecturers in the Department of Gender Studies for their advice. I also thank the Army Commander General Paul Mihova and Brig General Francis Kasempa from Special forces (Commando) and the rest of Command at different levels for their support and blessings.

\section{REFERENCES}

[1] Becker, C. T. (1975). Advanced chemistry thought, Madisons publishers, London.

[2] Cresswell, J.W. (2007). Qualitative Inquiry and Research Designs: Choosing Among Five Approaches, $2^{\text {nd }}$ ed. Sage Publishers, London.

[3] Creswell, J. W. (2007). Qualitative Inquiry and Research Designs: Choosing Among Five Approaches, 2 ed. Sage Publishers, London.

[4] European Commission (2006); Sexual Harassment in the Work Place in the European Union. Directorate - General for employment industrial Relations and social affairs unity V/DS.

[5] Foucault, M. (1975). Gender Power Relations Theories, University of Chicago Press, Chicango.

[6] Gallagher. G. (2008). Sexual Harassment and the US. Army: A Survey of Selected Military Academies, University of Kansa Publications, Kansas.

[7] Guba and Lincoln, J. (1994). Qualitative Research, Sage Publications, London.

[8] Malekinejad, M.; Johnston, L.G.; Kendall C; Kerr, L.R.; Rifkin, M.R., and Rutherford, G.W., (2008) Using Respondent-Driven Sampling Methodology For HIV Biological and Behavioral Surveillance in International Settings: A Systematic Review. AIDS and Behaviour, 12, S105-S130.

[9] Matakala, J. M. (2015). Sexual Harassment and Experiences of Female Soldiers on the Un Peace Keeping Operations, Dissertation, University of Zambia, Lusaka.

[10] Mohammed, G. (2014). Atlas $T 17$ Qualitative Data Analysis Software: Principles and Practice, Penguin Publishers, New York.

[11] Msabila, T. and Nalaila, G. (2013). Research Proposal and Dissertation Writing: Principles and Practice, Nyambari Publishers, Dar es Salaam.

[12] UNSC, (2008). Challenges for the Deployment of United Nations Peace Keepers in Mission Areas, United Nations, New York.

[13] Davidson, A. (2013). Military Sexual Harassment and Assault: Shameful Isn't Enough, The New Yorker Close Read Biog, New York.

[14] Deshamps, C. C. and Mills A F (2015) External Review into Sexual Harassment in the Canadian Armed Forces, Journal of social issues p687-702.

[15] Egaden S J, (2012). A Modern thought on advanced research and innovation: Developing of Toolkits and participatory action, penguin publishers,London.

[16] European Commission (2006); Sexual Harassment in the Work Place in the European Union. Directorate - General for employment industrial Relations and social affairs unity V/DS.

[17] Foucault, M (1975), Gender Power Relation Theories, University of Chicago, Chicago. 
[18] Gallagher. G. (2008), Sexual Harassment and the US. Army: A Survey of Selected Military Academies, University of Kansa Publications, Kansas.

[19] Giorgi, A et al. (1985), Phenomenology and Psychological ResearchDuquesne University Press, Pittsburg.

[20] Guba, I. and Lincolns (1994) Qualitative Research, Sage Publications, London.

[21] Hart, C. (2013). Doing a Literature Review: Release the Social Science imagination, Sage Publications, London.

[22] Kombo, D. K. and Tromp, L. A. (2006). Proposal and Thesis Writing: An Introduction, Pauline Publication Africa, Nairobi.

[23] Krueger, R. A. (1988). Focus Groups and Interviews: A practical Guide for Applied Research Methods. Sage Publishers, London.

[24] Leedy, A. and Ormrod, J. F. (2005). Practical Research Planning and Design. Merrill Prentice Publishers, New Jersey.Holloway and Wheeler (1996).

[25] Holloway, I and Wheeler, S. (1996).Qualitative research for Nurses Hartinolis limited, Paris

[26] Malekinejad, M; Johnston L G; Kendall C; Kerr L R; Rifkin M R and Rutherford G W (2008) Using Respondent-Driven Sampling Methodology for HIV Biological and Behavioral Surveillance in International Settings: A Systematic Review. AIDS and Behavior, 12, S105-S130.

[27] Merriam, C. (2015)Developing a female preventive participatory approach to prevent sexual harassment on female officer cadets, Journal of issues, 2015. 62 (2) 212-235

[28] Mirriam, C. (2012)Developing a female Preventive Toolkit to prevent sexual harassment in the Canadian forces, Journal of social issues, 40 (6) 31-45

[29] Matakala, J. M. (2015). Sexual Harassment and Experiences of Female Soldiers on the UN Peace Keeping Operations, Dissertation, University of Zambia, Lusaka.

[30] Penal Code (2013). National Assembly of Zambia, Sexual Harassment. Laws of Zambia; 29 October, 2013.

[31] Turchik, J. and Susan, W. (2010). Sexual Harassment, Assault in the United States Military: A Review of Literature and Recommendations for the Future, Aggression and Violent Behavior: Journal 266 - 277.

[32] SCGR, (2008). Measures of Stopping Sexual Harassments and Assaults in Peace Keeping Operations, United Nations Publication, New York.

[33] UNSC, (2008). Challenges for the Deployment of United Nations Peace Keepers in Mission Areas, United Nations, New York.

\section{AUTHOR'S BIOGRAPHY}
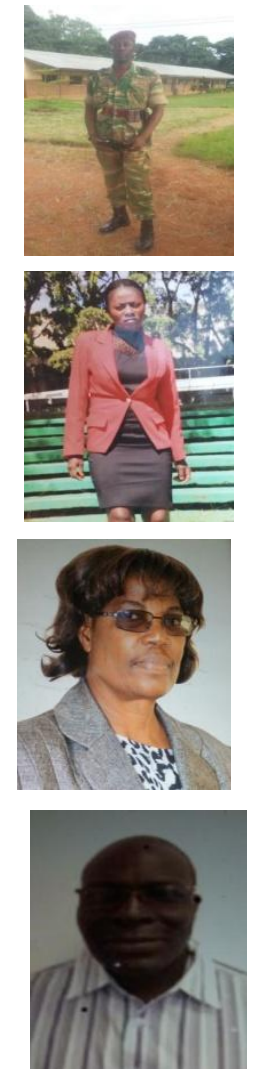

John Mwitumwa Matakala is a Doctor of Philosophy Reasearch Fellow in Gender Studies. At the University Of Zambia. He is the Principal Researcher. He is also Special Force Soldier in the Commando Unit. He is the Prinicipal Researcher.

Ivy Nawa Akabondo is a Master of Art Student in Gender Studies at the University of Zambia. She is the Assistant Researcher in this Study. She is also High School Teacher at Ingwe School in the Commando Unit. She is the Prinicipal Researcher.

Prof. Mubiana Macwan'gi, The Professor of Public Health The Principal Supervisor of the Study. Is at the Institute of Economic and Social Research University of Zambia. Director - 2010 to 2016 Senior Lecturer/Researcher Department of Gender Studies

Dr. Philemon Ndubani, The Doctor in Anthropology/Epidemiology is CoSupervisor of the Study Institute of Economic and Social Research, University of Zambia, Director - 2008 to 2010 Senior Lecturer/Researcher - Department of Gender Studies 
Gendered Phenomenological Perceptions on Characteristics of Sexual Harassment among Soldiers in Eastern, Zambia

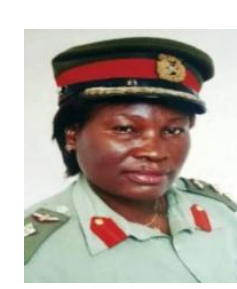

Dr. Annie Namakando Phiri (Rtd Col.), Co-Supervisor of the Study, the University of Zambia, Head of Department - 2013 to 2016. Senior Lecturer/Researcher Department of Gender Studies

Citation: John Mwitumwa Matakala, et.al. "Gendered Phenomenological Perceptions on Characteristics of Sexual Harassment among Soldiers in Eastern, Zambia". International Journal of Humanities Social Sciences and Education (IJHSSE), vol 5, no. 7, 2018, pp. 93-101. doi: http://dx.doi.org/10.20431/2349-0381.0507011.

Copyright: (c) 2018 Authors. This is an open-access article distributed under the terms of the Creative Commons Attribution License, which permits unrestricted use, distribution, and reproduction in any medium, provided the original author and source are credited. 